\title{
五ヶ瀬川支流北川における河道掘削による 河原形成システムの変質について CHANGE OF FLUVIAL SYSTEM CAUSED BY THE CHANNEL WIDENING IN THE KITA RIVER
}

\author{
服部敦 1 ・瀬崎智之 ${ }^{2} \cdot$ 福島雅紀 ${ }^{3} \cdot$ 伊藤政彦 $^{4} \cdot$ 末次忠司 ${ }^{5}$ \\ Atsushi HATTORI, Tomoyuki SEZAKI, Masaki FUKUSHIMA, Masahiko ITOU \\ and Tadashi SUETSUGI
}

\begin{abstract}
1正会員 工修 国土技術政策総合研究所河川研究部河川研究室 主任研究官 (テ305-0804つくば市旭1)
2 正会員 工修 国土技術政策総合研究所企画部企画課 建設専門官 (同上)

3 正会員 工博 国土技術政策総合研究所河川研究部河川研究室 主任研究官 (同上)

4正会員 株式会社ウエスコ技術部（７６51-0092 神戸市中央区生田町 $2 丁$ 目 2-2，元国土技術政策総合研究 所河川研究部河川研究室 交流研究員)

5 正会員 工博 国土技術政策総合研究所 河川研究部河川研究室 室長 (テ305-0804つくば市旭1)
\end{abstract}

In the Kita River, several large-scale widening of low channel have been carried out from 1998 to 2003 . To understand the impact of the widening on river ecosystem, field surveys are conducted at two investigation sites: Honmura and Matono districts. At Honmura district, where the widening of low channel has been carried out before 1982, variation of riverbed, plane distribution of vegetation and the thickness of surface soil layer were investigated. On the other hand, the sedimentation structure of the flood channel which have been formed in several hundreds years was surveyed at Matono District. It is inferred from these results that there would occur the extension of wetland covered with willow and phragmites community and the reduction of bare bars in the future after the widening of low channel in the Kita River.

Key Words : channel widening, river bed variation, river ecosystem, gravel bar, riparian vegetation

\section{1.はじめに}

近年, 出水時の流れや河道地形変化などの物理的作用 が植生の繁茂分布，遷移や流失などに与える影響とその

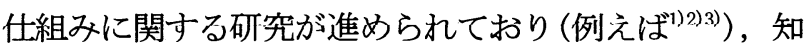
見の蓄積に伴ってある特定の生物種やハビタットといっ た個別対象だけでなく，様々な仕組みが連動することで 自律的かつ持続的な生物生息・ハビタット形成を可能と する系として捉えられる河川のシステム(Ecosystemの一 部としてのFluvial System)も保全する必要があるとの 認識が広がりつつある゙．本研究でも対象としている砅 床河川では，樹林化による河原减少がシステムの概念か ら環境保全を考えるべき重要課題の一つとして取り上げ られることが多い. しかし，この課題だけに絞っても， 個別な仕組みに関する研究の進展がありながらも，未だ システム全容を捉えるには至っていない，そのため，シ ステムや仕組みに関する知見が，例えば河道掘削などの 河川事業がもたらす環境変化影響予測や，自然再生のた めの事業計画の検討において，中心的役割を担うには
至っていないと考えている. 本研究は, より実用性を増 すための研究の一段階として, 大規模な河道掘削を実施 した五ヶ瀬川支流の北川を対象として，掘削終了からの 経過年数を $1,10,100$ 年スケールに分けて, 各時間スケー ルでの地形変化パターンとその進行速度, 植物群落分布 を現地調查結果に基づいて推定し，河道管理の立場から 見て重要な 1 10年スケールの変化についてシステムと しての解釈を加えることを試みたものである. 特に, 砂 砅堆の形成に伴って掘削前に近い高さ (平水位からの比 高が約 $3 \mathrm{~m})$ の砂砂堆が形成されること, そのような高い 砂䃇堆が 20 年程度で形成される理由の一つとして, 前縁 線部で砂層を埋めながら砂磷堆が前進するためであるこ と,について詳細に検討を加えている.

\section{2. 河道特性·激特事業の概要と調査地点の選定}

北川では, 1997 年に熊田観測所で既往最大のピーク 水位となる TP. $16.79 \mathrm{~m}$ (ピーク流量 $5,067 \mathrm{~m}^{3} / \mathrm{s}$ )の出水が 生じ, 谷底平野のほぼ全域が冠水する甚大な被害を受け 

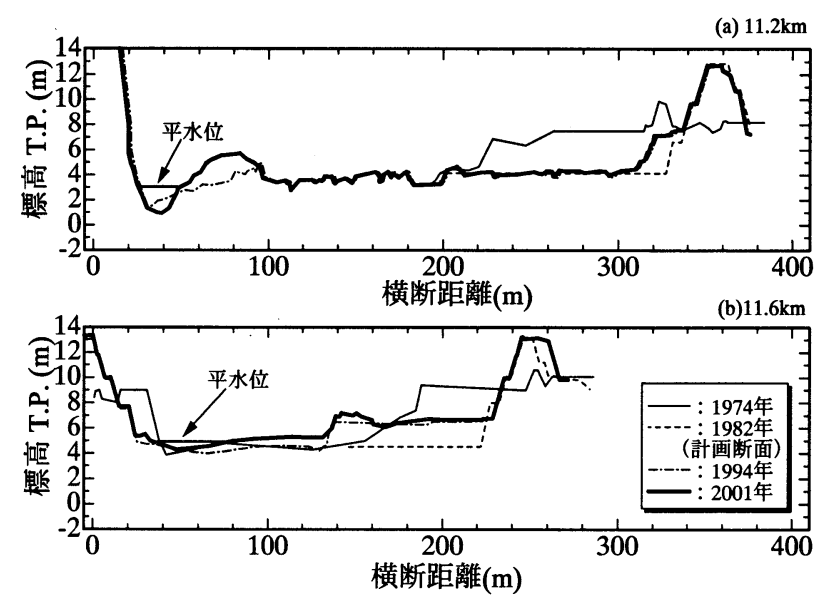

図-1 本村地区の横断形状

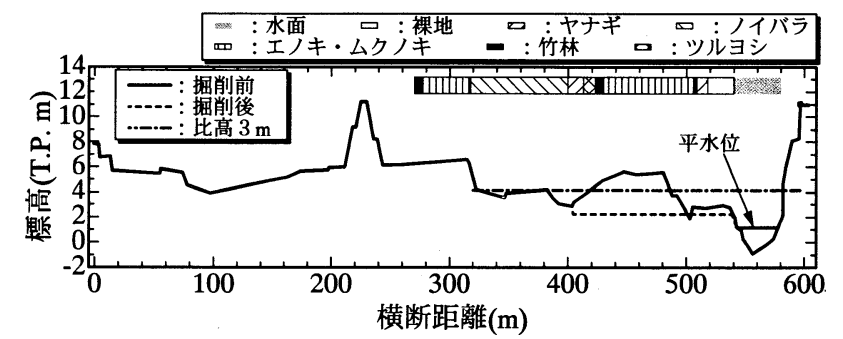

図-2 横断形状の一例(的野 $9.4 \mathrm{~km}$ )

たことから，河川激甚災害対策特別緊急事業(以下，激 特事業と呼ぶ)に採択された。この激特事業では, 支川 の小川合流点 $(15.05 \mathrm{~km})$ から河口までが対象区間となり, 高水敷を比高 $1 \mathrm{~m}$ 程度まで掘削する河積増加を主とする 改修が行われている.この区間での谷底平野の幅は堤間 距離の 2〜3 倍程度と狭く, そのため河道は山腹に衝突 して蛇行している. 現地調査対象とした本村地区(11〜 $12 \mathrm{~km})$ と的野地区 $(8.8 \sim 9.8 \mathrm{~km})$ は，そのような湾曲部で あり, 湾曲の向きを除き平面形状は類似している. また, 本村地区は約 20 年前に, 的野地区では激特事業で河川 敷の掘削が行われている. 両地区を含む $4.2 \sim 16 \mathrm{~km}$ まで の区間は, 河床材料の平均粒径が $20 \sim 40 \mathrm{~mm}$, 河床勾配 が約 $1 / 1200$, 平均年最大流量は $1,850 \mathrm{~m}^{3} / \mathrm{s}$ である.

本村地区では, 写真-11) (4)(以下, (1) (4)と表現す る)に示すように約 20 年前に内岸の高水敷が 2 回程度に分 けて掘削されている. 掘削前後の河道横断形状の一例を 図-1に示すが，激特事業之同様に比高1m程度まで掘削さ れたことが分かる. 以上から本村地区での変化(3)〜(4)は, 激特事業後に 10 年スケールで起こりうる一変化パターン と考えられる.

的野地区では，図-2に示すように横断距離 $400 \sim 500 \mathrm{~m}$ に位置する凸部を2001〜2002年度に掘削した．掘削完了 直後の 2003 年に平均年最大流量とほぼ等しいピーク流量 の5月末出水のほか, 指定水位を超える小出水が3回発生 し(以下, 2003 出水と呼ぶ), 写真-2に示すように平坦で あった掘削面上に砂䂰堆が形成された. 5月末出水の生 起確率年が2〜 4年程度であることも踏まえると，この変 化は掘削後1年スケールで起こりうると考えられる.

さらに掘削時に凸部の堆積層を調査したところ, 堆積
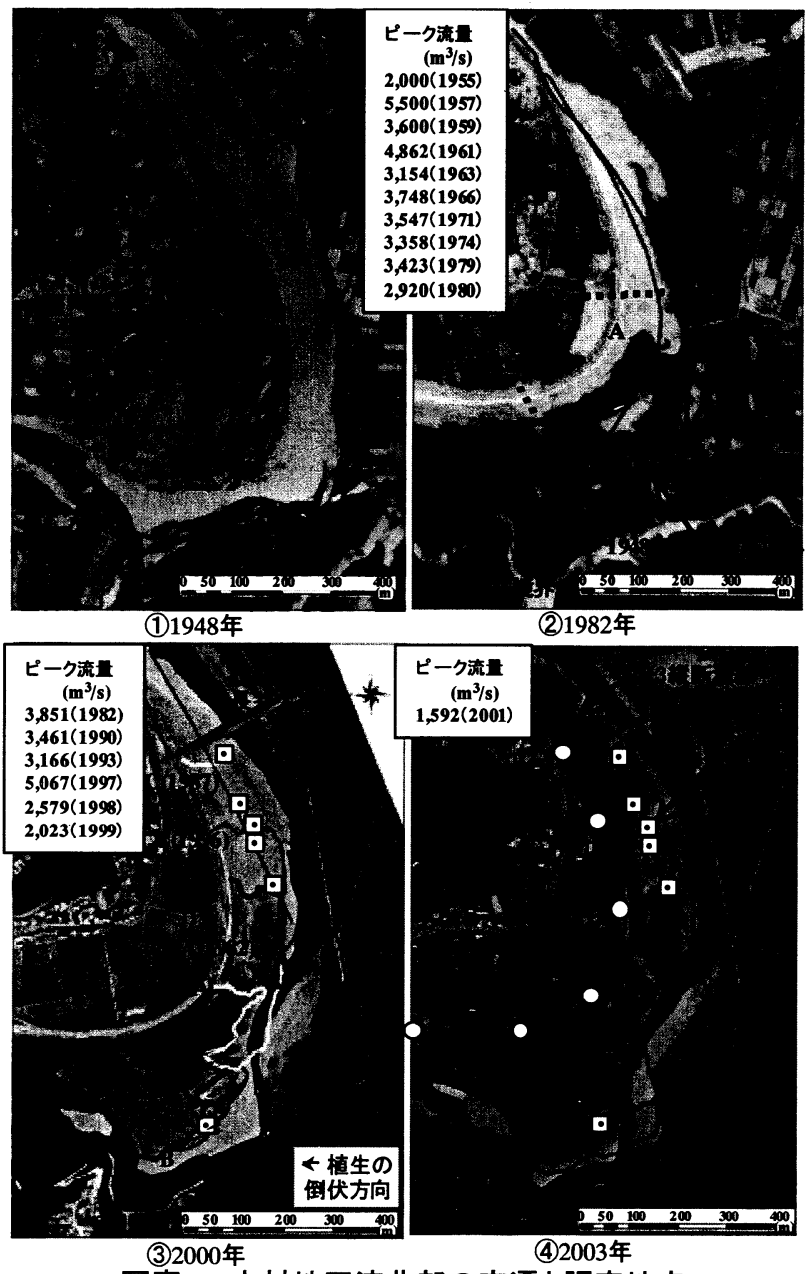

写真-1 本村地区湾曲部の変遷と調査地点

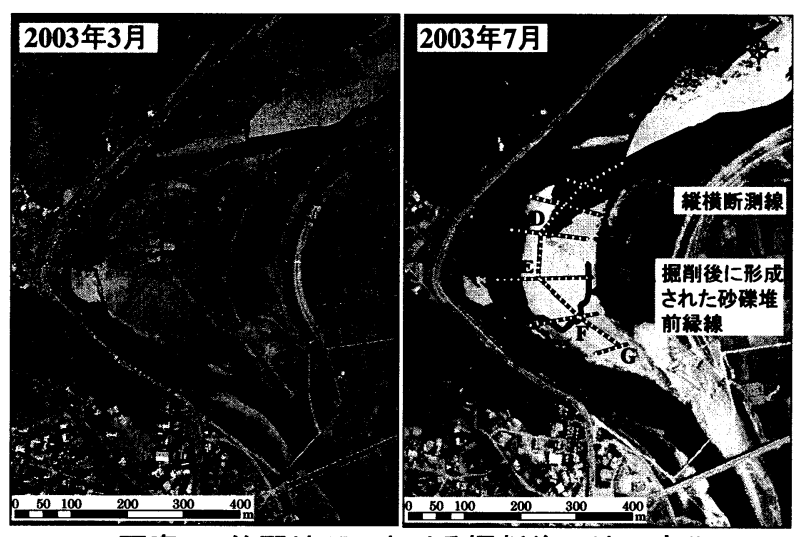

写真-2 的野地区における掘削後の地形変化

層序に本村地区との類似点が多く, 今回の掘削面程度の 高さであったテラス上に砂磘が堆積することで形成され た地形と推定された.この地形形成の始まりは後述する 堆積年代測定結果によると少なくとも 900 年前であるこ とから, 比高3〜4mの河川敷が再形成する100年スケール の変化として捉えられる.

以下では, まず河道管理上, 最も興味深い 10 年スケー ルの変化が見られた本村地区での変化パターンについて 3.で記述し，本村地区での調査のみでは明らかにできな かった事項について的野地区の両スケールでの変化パ ターンを援用して考察を加えた結果を4., 5. に示す. 


\section{3. 本村地区における地形と植生の現地調查}

\section{(1) 航空写真から見た砂喽堆の形成と拡大過程}

写真-1の河川敷に見える色の薄い領域之濃い領域は, 砂㗭堆が植生に乗り上げることによって生じる色の違い であることが，現地観測によって確認されている．写 真-1には, この色の境界によって判読した砂磷堆前縁線 の位置を示した. (3)には, A, B,Cの3つの砂礫堆前縁線 (太い害線)を確認できる.

砂礫堆Aは1982年に11.6kmより下流堤防側に存在する 裸地部分を起源とし，1987年(3)の白線)までに多少下流 に拡大しているが，これ以降ほとんご拡大していない (4)参照)。このように前縁線の前進が停滞した場合には, その上流側の裸地にツルヨシなどの植生が繁茂すること が過去の航空写真や現地調査から確認されており，(3) (4)の変化でもこのことを確認でき前縁線は不明瞭となる. 砂磷堆Bは潜水橋の取り付け部を起源として, 中規模 の出水が 2 回発生した1987〜 1996年にかけて 200m以上大 きく拡大する. ただし，水際に沿った方向への拡大が主 であり, (3)に示した流向への搪大は20m程度と小さい. ここで，流向は2001年10月出水 (ピーク流量 $1,592 \mathrm{~m}^{3} / \mathrm{s}$ ) 後に河川敷上の草本植物の倒伏方向をGPS測量によって 調べた結果である. 激特事業のきっかけとなった1997年 出水後の 2000 年の前緑線を見ても, 流向への砂砂堆の拡 大は11.2〜11.3kmまでの範囲で最大 $70 \mathrm{mに}$ 限られ，他の 部分の前縁線はほとんど変化していない．また，2000年 以降については砂碟堆A之同様に砂磁堆Bもほとんど拡大 せず，前縁線上流部の裸地は植生に覆われている.

上流の直線部にある砂群堆Cは(3)の長井大橋下流に出 現し，前縁線全体が1987～1996年で140m，1996～2000年 で140mと大きく挔大し続けている. この拡大の際に, 砂 礫堆はツルヨシなどの植物を押し倒し前進することが現 地調査で確認されている．2000年以降の変化については， 砂磷堆A, B同様に抆大していない.

以上より, 砂喤堆は湾曲部では水際に沿って速く拡大 するものの, 内岸側へはゆっくりと拡大することが分 かつた. なお，この拡大速度については4.でさらに検討 を加える. また，準二次元不等流計算 ${ }^{5}$ によって平均年 最大流量に対する本村地区の無次元掃流力 (低水路内の 断面平均値) の縦断分布を求めると, 湾曲部上流の直線 部において0.06以上であるのに対して，11.1〜11.3kmで は0.03程度の值となっている。これは，11.3km付近で磷 堆が停滞する十分な根拠となろう.

\section{（2）地層構造から見た砂磁堆の形成と拡大過程}

写真-1に示すトレンチ掘削点において，2003年3月に 地下水面が現れるまで掘削を行い，地層の厚さおよび主 要構成材料の粒径を調査した. 図-3に砂礫堆Cの縦断形 状および地層構造を示す. 1996年に300m付近にあった前 縁が，2000年には550m付近まで前進し，地表面の高さも

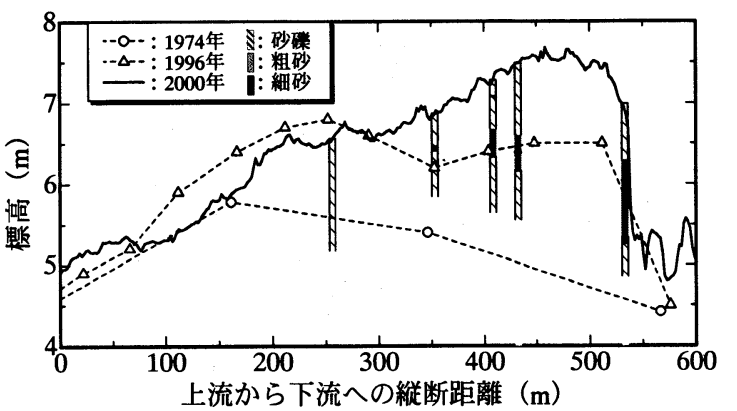

図-3 砂州の形状と地層構造

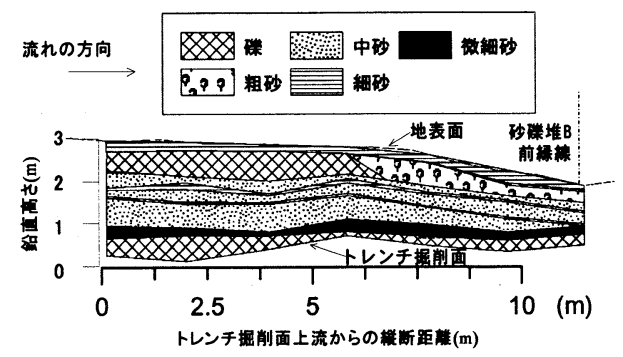

図-4 砂喽堆B前縁部での地層構造

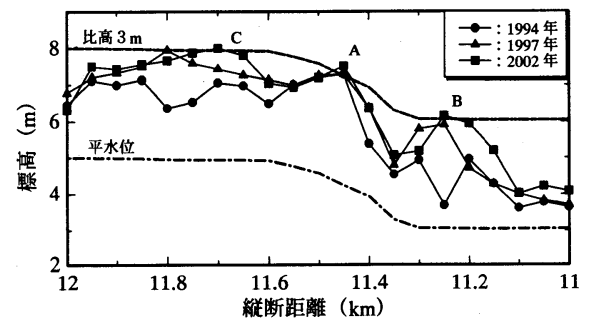

図-5 砂州高と平水位との関係

上昇している．地層を見ると，1996年の前縁線の下流に 形成された砂層上に碟が堆積している．1974～1996年の 約20年間における砂磘堆の標高の上昇が約1mであったこ とを考慮すると，1996～2000年の4年間での約1mの上昇 はかなり急激なものであったと言えよう．また，350〜 $450 \mathrm{~m}$ の砂層厚が0.2〜 0.5mであるのに対して, $530 \mathrm{~m}$ 付近 の砂礫堆C前縁部では, 1m以上の厚い砂層が見られる.

このような厚い砂層は, 図-4に示す砂喽堆Bの前縁部 にも見られる.ここでは, 砂磘堆Bの前縁線から上流側 に $10 \mathrm{~m}$ 以上の長さのトレンチを掘削し調査を行った. そ の結果, 鈶直高さ0.5 0.8mの群層上に厚さ $1 \mathrm{~m}$ 以上の砂 層が堆積し，その砂首上に縦断距離6田の位置までは磁が， それより下流側は粗砂が堆積していた.これは, 喽が移 動できない中小規模の出水時に, 砂磷堆上を流下した粗 砂が砂喽堆の下流に堆積して形成された層であると考え られる.ここでも, 砂啋堆の下流にはツルヨシなどの植 生が存在していたが，それらを埋めて砂磎堆が前進する. 以上より, 砂層を埋めながら砂礫堆が前進することで, 河川敷の高さは急激に上昇することが分かった. しかし ながら，その上昇量にはある上限值があるようである.

図-5は，50m間隔で実施された横断測量結果から砂礫堆 の最高点を抽出し, その縦断分布として整理したもので ある.これによると, 砂礫堆 $A, B, C の$ 前縁はいずれも比 高3mの線で包絡され，この高さを境界値として碟の堆積 による砂䃯堆の比高の増加は生じにくいものと考えられ 


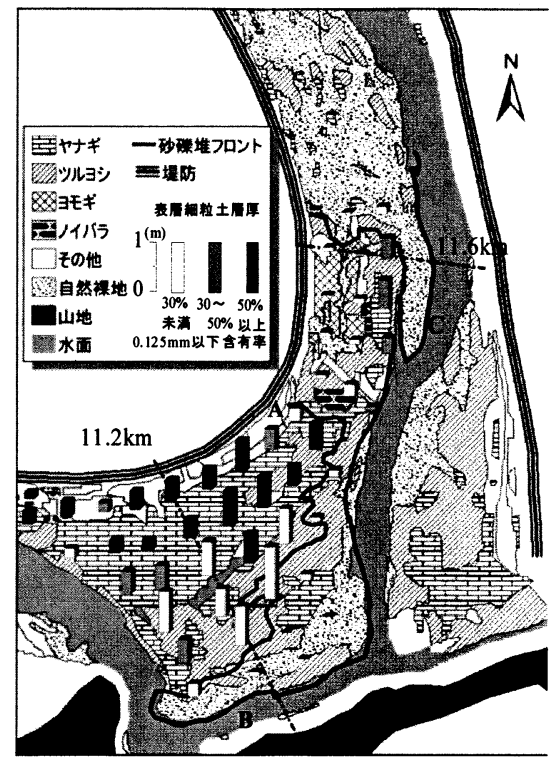

図-6 本村地区の植生と表土の分布

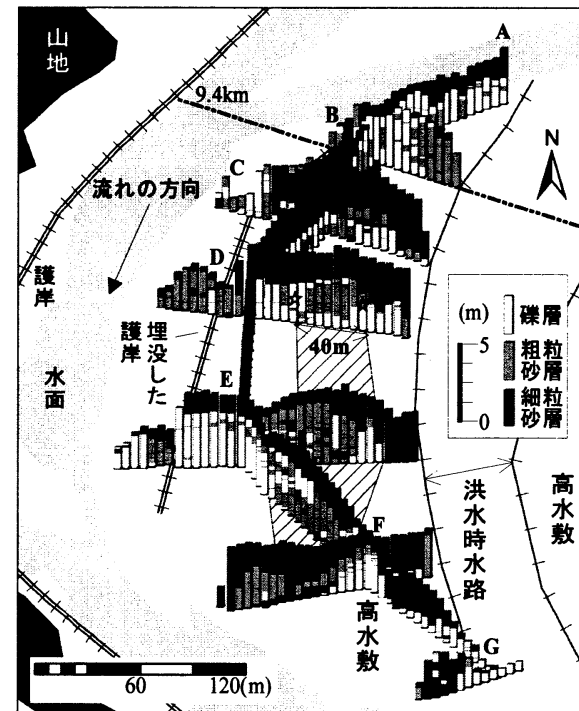

図-8 的野地区の地層構造調査結果

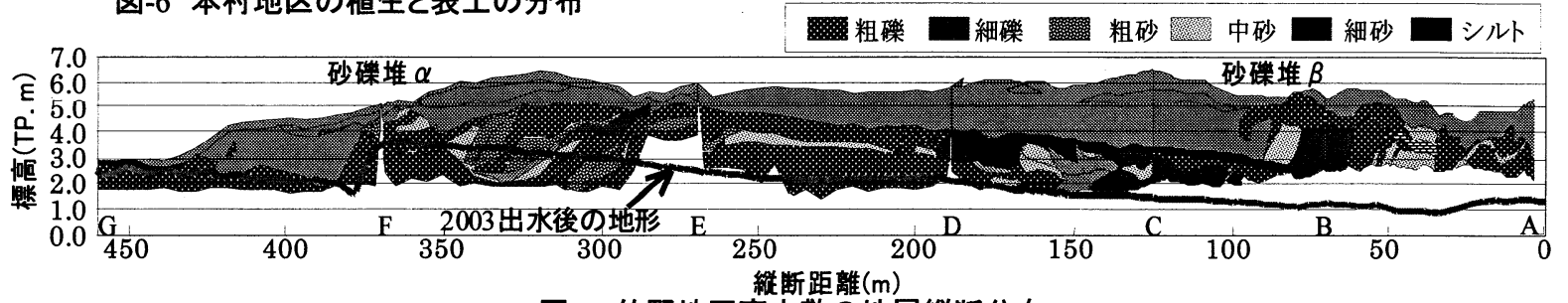

図-7 的野地区高水敷の地層縦断分布

る. ここで, 川幅水深比, 水深粒径比から砂磼堆の高さ を算定すると ${ }^{6} ， 3 \mathrm{~m}$ 程度の高さまで砂䃯堆が発達したこ

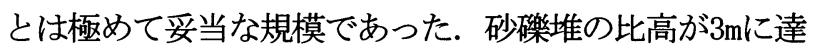
した後の地形変化については, そのヒントを図-4および (4)に見ることができる. 図-4の表層には細砂層が見られ， (4)からはこの部分に植生が繁茂していることを確認でき る. 現地調査によると, ツルヨシを主体とする植生であ ることが確認されており，この程度まで河川敷が高くな ると, 碩は移動しにくくなり, 地表面には細砂が堆積し, ツルヨシ等の植生が繁茂し始めるものと予測される. な お，この地形変化に関する予測については4. で確認する.

\section{（3）表層細粒土層と植生分布}

図-6は，2001年1月に調查した表層細粒土層厚(検土杖 で測定した砶面上の砂・シルト層の厚さ) と1999年の本 村地区の植生図 ${ }^{5)}$ 示す. 砂碑堆上には厚さ $10 \mathrm{~cm}$ 以下の 薄い表層細粒土層しか形成されていないが, 砂砂堆が到 達していない砂砅堆A, Bより下流の内岸側には全面的に 厚さ $50 \mathrm{~cm}$ 以上の厚い表層細粒土層が形成されている.こ れは, 前述した湾曲部における急激な掃流力の低下に よって, $11.3 \mathrm{~km}$ 付近に碟や砂が堆積し始め, その上流側 には比高の高、砂砅堆が形成される. 湾曲部内岸は, こ の砂砅堆の背後地となり流速がさらに低下するため, 細 砂やシルト・粘土が堆積しやすくなる.この細粒土砂の 堆積によってツルヨシなどの植生が繁茂し, 細砂やシル ト・粘土がさらに堆積しやすい環境とする.このことは, 微細砂以下 $(0.125 \mathrm{~mm}$ 以下) の土粒子成分の含有率(以下,
微細砂含有率と呼ぶ)にも顕著に表れており，外岸側や 砂㗭堆の乗り上げ部での微細土砂含有率が小さいのに対 して, 内岸側では微細砂含有率が大きい土層が形成され ている.

植生分布に着目すると，本村地区の河川敷には北川の 低水路に生育する植生や裸地が主に分布している. その 種類は，表層細粒土層厚によって明瞭に分布域が分かれ， 近年砂䃯堆の拡大があった砂碟堆B, C上には裸地が，近 年砂砅堆の拡大がない砂砅堆 $\mathrm{A上にはノイバラ,} \mathrm{ヨモギ}$ が分布している. 一方, 表層細粒土層が厚い部分では, 微細砂含有率の高い内岸側の部分にはヤナギが, 微細砂 含有率の低い澪筋側の部分と砂碟堆A上への乗り上げ部 にはツルヨシが分布する. ちなみに, ヤナギの特性とし て，種子は長時間にわたって湿地であるような場所でな いと発芽しないことが知られている. この表層細粒土層 厚と微細砂含有率によって決定される植生分布に従って, 6. では低水路拡幅後の植生の繁茂状況を予測する.

\section{4. 的野地区における地層構造と地形変化}

\section{（1）砂碟互層の地層構造}

激特事業による掘削時に，写真-2に示寸的野地区の縦 横断測線上に露出した掘削断面の地層を区分し，この地 層境界を測線方向 $5 \mathrm{~m}$ ごとに測量した. 図一 7 , 縦断測線 に沿った地層断面を示寸．地層の下位には，本村地区の トレンチに見られたような砂碟堆によって形成されたと 
判断される砂層と碟層の互層が見られる. その砂砶堆の 上位には細砂層が存在する. 砂砶堆はC〜Fにかけて(以 下, 砂砅堆 $\alpha$ と呼ぶ) とA〜Bにかけて（以下，砂砅堆 $\beta$ と 呼ぶ)の 2 つ存在し, 前縁部の比高は両者とも3〜 $4 \mathrm{~m}$ で本 村地区のそれに等しい(平水位は $2 \mathrm{~m}$ 程度). 地表面は, 砂 礫互層の高さによらず，細砂の堆積によって比高 4 ～5m の比較的平坦な地形となっている.

下位の砂砶互層中の砂層に着目すると, 砂砶堆 $\alpha$ のD

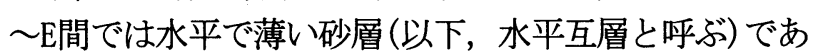
るのに対し, 砂砅堆 $\alpha, \beta$ 前縁付近では垂直あるいは 傾斜した厚い砂層(以下, 鉛直互層と呼ぶ)であることが 分かる.これも本村地区でのトレンチ調査で見られた構 造と類似しており，E～F間では砂碟堆 $\alpha$ の比高が急激に 増加したことを示唆する. また, 砂砅堆 $\beta$ は長期間にわ たって停滞していたと考えられ，下流側の厚い細砂層は その際に形成されており，一度の出水で大きな比高を持 つ砂砶堆が形成されたと類推される.

このような鉛直互層は，横断測線中にも見られる. 図-8には各地層を主要構成材料に応じて, 細粒砂(シル 卜, 微細砂, 細砂 : $0.125 \mathrm{~mm}$ 以下), 粗粒砂 (中砂, 粗砂, 極粗砂: 0. 25〜2mm), 碟 ( $2 \mathrm{~mm}$ 以上) の 3つに区分し, 地 層俯瞰図として示している. 砂礫堆 $\alpha$ の鉛直互層は左斜 め下向きのハッチで示すベルト状の領域に分布し, それ より水際側は水平互層が形成されている. すなわち, 湾 曲部水際側では砂砅堆が速く拡大し, 湾曲部内岸側で拡 大速度が遅くなる.これは，現在の本村地区における砂 礫堆A, Bの拡大過程と共通点が多く, 本村地区の地表面 に細粒土砂がさらに堆積したものが的野地区の地層構造 であり，的野地区の高水敷は本村地区の将来の姿を示す ものと考えられる.

\section{（2）鉛直互層の拡大速度および水平互層の堆積速度}

図-8に乞印で示される40m離れた鈶直互層両端の砂層 に含まれる表層の有機物を採取し, AMS法(Accelerator Mass Spectrometry)による炭素年代測定を行った. この 結果, 水際側の地層はAD960土60年(94\%精度)に形成され, 内岸側の地層はAD1420土25年(95\%精度)に形成されたこ とが分かった. 両砂層間には5〜20mの間隔でさらに $3 つ$ の砂層が存在し，その年代差が約 400 年であることから， かなり大規模な出水時に砂䃇堆の拡大と縮小を繰り返し ながら，徐々に形成されたものと考えられた.

一方, ベルト状領域より内岸側には砂砶堆 $\alpha$ が到達せ ず比高0～ $1 \mathrm{~m}$ の砅層上に $3 \mathrm{~m}$ 以上の厚い細粒砂層が形成さ れている. この細粒砂層の有機物数点について年代測定 を行った結果, 約300年前に形成された地層であり,こ こ300年以内で $3 \mathrm{~m}$ の細粒砂層が堆積したことが分かった.

\section{(3) 植生分布}

激特事業によって河道が掘削される前の的野地区の河 川敷には, 図-2に示すように, 比高4～ $5 \mathrm{~m}$ の部分には竹

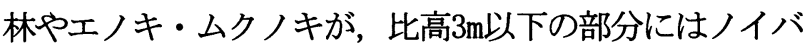
ラ・ヤナギ・ツルヨシが分布していた. これは, 比高の 増加に伴うツルヨシなどからエノキ・ムクノキへ遷移が 生じた結果であると考えられる. ただし，どの程度の比 高が境界となっていたかについては明らかでない。

\section{5. 的野地区における掘削直後の地形変化}

前章までは，10〜100年スケールの現象を見てきたが, ここでは, 掘削直後の出水による砂礫堆の形成過程につ いて，2003出水後の地形変化を例として考察した. 図-3 の1974年の砂砶堆は1回目の掘削後に形成された地形と 考えられるが，一部の地層から類推すると碟で構成され ている. 図-7の標高2m付近の砂砶堆も主に砶で構成され ている. 図-7には，掘削直後に発生した2003出水に伴う 地形変化も示した(平面形状は写真-2参照). 掘削直後の 平坦面の標高は $2.1 \mathrm{~m}$ であったが, 洪水の作用を受けて変 形し, 砂碩堆 $\alpha$ に相当する地形がほぼ形成されたことを 確認できる. 2003出水は平均年最大流量規模の出水であ り，2〜4年に1度発生するような高頻度の出水であるこ とから, 掘削後数年程度で図-3,7の下位に見られる砂碟 堆が一度の出水で形成されるものと考えられる.

\section{6. 北川における河原の形成システムの変質}

ここでは，前章までの解析結果を援用して，低水路が 拡幅された場合の河川敷の変化を推測する(図-9参照). 掘削後数年で, 掘削面上の砶が全面的に移動するような 出水によって, 掘削面上に砂砶堆が形成される. その際, 砂碩堆前縁部下流および内岸には細砂やシルトが堆積す る(図-9(1)参照)，砂碩堆下流もしくは内岸には，碩が移 動しないような中小の出水時にも砂やシルト・粘土が堆 積し，ツルヨシ，ヤナギを主体とする植生が形成される (図-9(2)参照).大出水時には砂砶堆は拡大し(平均 $10 \mathrm{~cm}$ /年), 上流もしくは外岸側に次の砂䃇堆が形成される. この矽碟堆の拡大範囲のツルヨシ・ヤナギは砂層ととも に砶層下に埋没する. 砂砶堆によって比高3mに近い高さ の地表面が形成された場合，砂礫堆の拡大速度は極めて 小さくなり, 砂䃯堆の背後や表面には細粒砂が堆積しツ ルヨシなどの植生が繁茂する(図-9(3)参照).

湾曲部の内岸など砂砅堆が到達するまでに極めて長期 間を要する箇所では, 砂礫堆下流の土砂の堆積が進み (平均 $1 \mathrm{~cm} /$ 年), 砂砅堆が到達する前に砶が移動しない ような比高まで地面が上昇する.この場合，当初形成さ れたツルヨシ・ヤナギの群落が比高の増大に伴って，エ ノキなどの樹林へと遷移する ${ }^{1)}$ (図-9(4)参照).

以上の知見より，北川におけるシステムを整理すると 以下のように表現しうる. 河川敷は大別して，植生が形 成と流失を繰り返す河原領域と, 比高の高い河川敷が再 


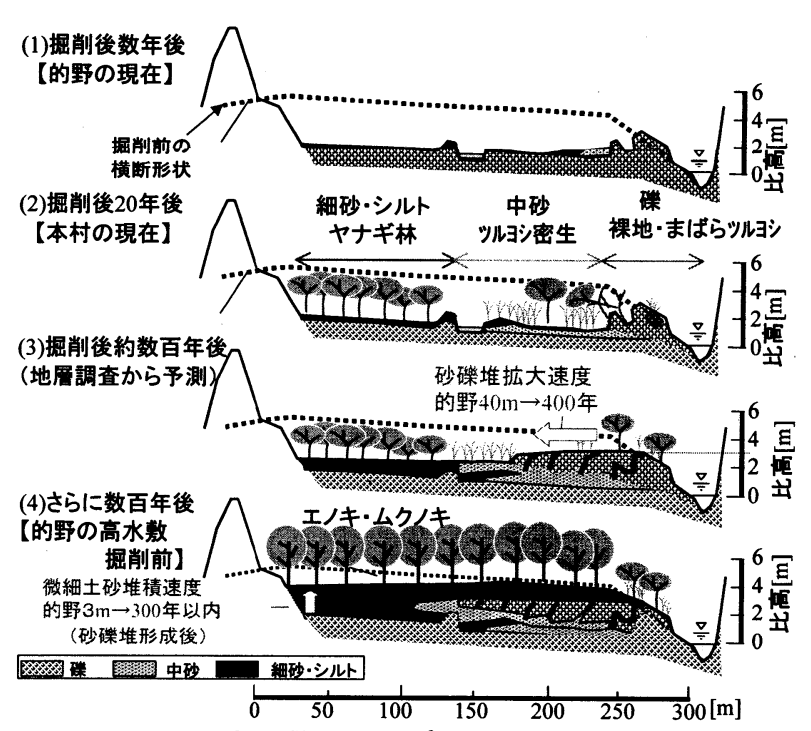

図-9 高水敷再形成プロセスの模式図

形成されるプロセスによってエノキ林に至る領域とで構 成されると捉えることができる. ツルヨシやヤナギの分 布域は，河川敷の比高が増加する中で一時的に存在する ものであるから, 砂州の変形が活発でない本来の北川で は，それほど広くなかった．しかし，低水路拡幅後河川 敷が元の状態に戻るまでには数百年単位の期間を要する ことから，エノキが生育する比高の高い河川敷に代わっ てヤナギやツルヨシの分布する低湿地が長期間, 広い範 囲に形成される. その理由は, 以下に示寸低水路拡幅前 後の擋乱頻度の違いから説明できる.

既存の知見によると尚，ヨモギなどの根茎が浅い植物 (以下, 浅根茎植物と呼ぶ) は中央粒径程度の河床材料を 移動させる掃流力が作用した場合に，またツルヨシなど の根茎が深い植物 (以下，深根茎植物と呼ぶ) は河床材料 の $90 \%$ 通過粒径を移動させる掃流力が作用した場合に流 失する.ここでは，9.4kmに位置する的野地区の横断面 (図-2参照)を一例として，掘削前の裸地表面に相当する 比高約 $1.7 \mathrm{~m}$ と掘削後の表面に相当する比高 $1 \mathrm{~m} の$ 地点で植 物が流失する頻度を算出し, 図-10に示した. 算出にあ たっては，芦田・道上の混合粒径の限界掃流力式を用い， $\mathrm{d}_{\mathrm{m}}=25 \mathrm{~mm}, \mathrm{~d}_{60}=30 \mathrm{~mm}, \mathrm{~d}_{90}=70 \mathrm{~mm}$ として浅根茎植物と深根茎植 物の流失限界を算出した. 準二次元不等流計算によって エネルギー勾配と水位を求め, 無次元掃流力を算出した さらに, 熊田観測所の水位データから流量の生起確率を 推算し, 無次元掃流力と流量の関係を整理した.

低水路拡幅の結果, 裸地であった部分は比高が小さく なっているにもかかわらず，ヨモギなどの浅根茎植物の 流失頻度は 0.9 年に 1 度から 2 年に 1 度に, ツルヨシなどの 深根茎植物は 1.2 年に 1 度から 6.5 年に1度に低下寸ること が分かる．もちろん掘削前はその影響を受けることがな かった年数回程度発生するような小規模の出水の影響を 受けるようになるが, このような出水は植生の繁茂を促 進する微細土砂を供給するのみである. すなわち, 単に 低水路を掘削すれば河原領域が拡大するわけではなく, 洪水摚乱の頻度に着目して掘削幅を検討すべきである.

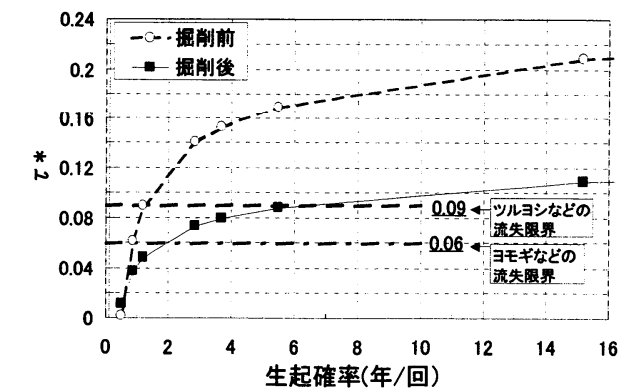

図-10 裸地領域における掘削前後の擋乱頻度の変化

\section{7. まとめ}

激特事業で低水路掘削が行われた北川を対象として, 掘削後の変化を予測した. 今後このような治水事業等に 伴う河道掘削が行われる機会が増えると予想され, シス テムとして見た時のインパクトに対するレスポンスを予 測する手法を身に付ける必要がある.ここでは, 礫床河 川である北川の事例から，河川敷の比高の増加にとって 砂碟互層構造が重要であることを示した．このような 個々の仕組みを組み込んだ数值モデルの構筑を今後目指 していきたい. 最後に, 本研究で示した地層の調査手法 は, 河道掘削後のレスポンスの速度を評価する上で非常 に有効な手段であることを述べておく

謝辞 : 本研究は北川における河川生態学術研究会の総合 的な調査研究の一環として実施されたものである. 本村 地区での砂礫堆の縱断形状は, 宮崎大学杉尾教授, 佐賀 大学渡邊教授より調査データの提供を受けた. また, 宮 崎県延岡土木事務所には的野地区の高水敷地層調查等多 大な協力を得た. ここに記して謝意を表する.

\section{参考文献}

1）石川慎吾 : 揖斐川の川辺植生 II. 扇状地域の砂碑堆上の 植生動態, 日本生態学会誌, Vol. 41, pp. 31-43, 1991.

2）李参熙, 藤田光一, 塚原隆夫, 渡辺敏, 山本晃一, 望月達 也 : 磘床河川の樹林化に果たす洪水と細粒土砂流送の役割, 水工学論文集, 第42巻, pp. 433-438, 1998.

3）瀬椅智之, 服部敦, 近藤和仁, 徳田真, 藤田光一, 吉田昌 樹: 砅洲上草本植生の流失機構に関する現地調查と考察, 水工学論文集, 第44巻, pp. 301-306, 2000.

4）服部敦, 瀬崎智之, 伊藤政彦, 末次忠司 : 河床変動の観点 で捉えた河原を支える仕組みの復元一多摩川永田地区を事 例として一, 第9回河川技術論文集, pp. 85-90, 2003.

5）建設省九州地方建設局, 宮崎県 : モニタリング調査結果, 北川モニタリング委員会専門部会資料，pp. 3の2-4の54, 2000.

6) 山本晃一: 沖積河川学 堆積環境の視点から, 山海堂, pp. 458-462, 1994.

(2003. 9. 30受付) 